\title{
A component method for moment-resistant glulam beam-column connections with glued-in steel rods
}

Huifeng Yang*, Weiqing Liu, Xiao Ren

College of Civil Engineering, Nanjing Tech University, Nanjing 211816, China

\begin{abstract}
This paper presents an analytical method of the determination of the moment resistance, initial stiffness and the rotation capacity of glulam beam-column connections with glued-in rods. The methodology is based on the component method and is implemented using appropriate mechanical models. As a simplified component of the steel box sections, the substitute T-stub in the model is well verified by the experimental results, whether with or without the transverse web stiffeners. On the basis of the mechanical properties of the individual components such as initial stiffness, load resistance and a further force-deformation relationship, the moment-rotation curves of the entire joint can be obtained. The proposed model is evaluated against the experimental results, which shows good agreement between the two.
\end{abstract}

Keywords: Connections; Timber structures; Glued-in rods; Component method; Initial rotational stiffness; Moment resistance; Rotation capacity.

\section{Introduction}

\footnotetext{
* Corresponding author. Address: College of Civil Engineering, Nanjing Tech University, South Puzhu Road 30, Nanjing, 211816, China. Mobile: +86 13913821169; Fax: +86 2558139862.

E-mail address: hfyang@njtech.edu.cn (H. Yang)
} 
Wood is renewable and sustainable, and it also has the lowest energy consumption and the lowest carbon dioxide emission among many building materials. Thus it is one of the world's most environmentally friendly building materials. Connection is critical for structural timber or steel design. And the ductility and energy dissipation behavior usually depends on the connections for timber structures, since timber elements are regarded as behaving elastically $[1,2]$. The capability to dissipate energy of ductile connections provides some benefits, such as the integration to the earthquake analysis and in addition to increase the robustness of the structure [3].

A possible solution for the ductile moment-resistant connection is glued-in steel rods connection. Some attractive properties presented by this kind of connections include high strength, high stiffness, and aesthetic appearance. Furthermore it can provide a higher adaptability of geometrically complex connections. The use of this technology began in Denmark about 1980. A great number of research has been carried out on pull-out behavior of glued-in rods joints [4-8] and a comprehensive review of early efforts involving it can be found in the literature [9]. Also some research was carried out on moment-resistant behavior of timber connections with glued-in rods [10-20], which is the focus of this paper.

\subsection{Moment-resistant timber connections with glued-in rods}

Buchanan and Fairweather [10] executed an experimental investigation on moment-resisting glulam beam-column connections using glued-in rods with and without steel brackets (see Fig. 1). Test results showed that brittle splitting fracture of glulam column occurred in connections using glued-in rods in both beam and column of the connection without steel brackets. As providing some un-bonding length of each rod at beam-column interface, the excellent hysteresis loops showed good ductile behavior almost similar to that of a steel structure. Nevertheless it is inconvenient for the in-situ gluing process due to the requirement of some special conditions [12]. Buchanan and Fairweather [10] therefore 
designed another group of specimens with steel connecting brackets. Then under a capacity design, it could ensure that the ultimate fracture would be the ductile failure of steel brackets rather than that of wood, adhesives, or other non-ductile component. Moreover, the addition of the steel component allows a practical application and easy assembly of this kind of structures [13].

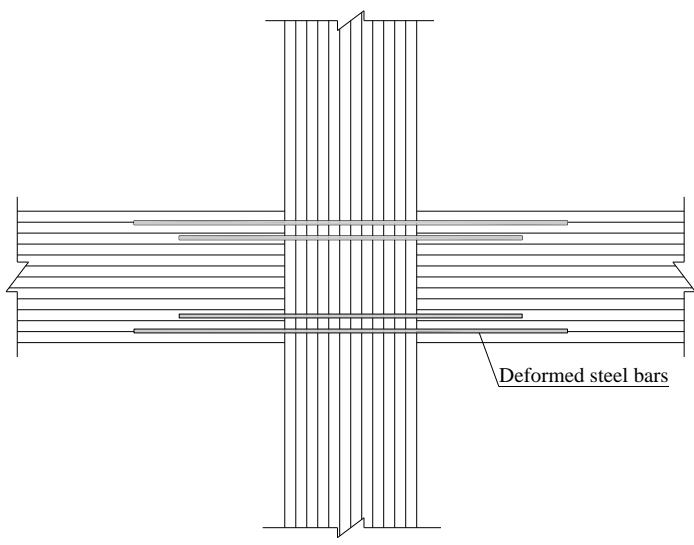

(a) Without steel brackets

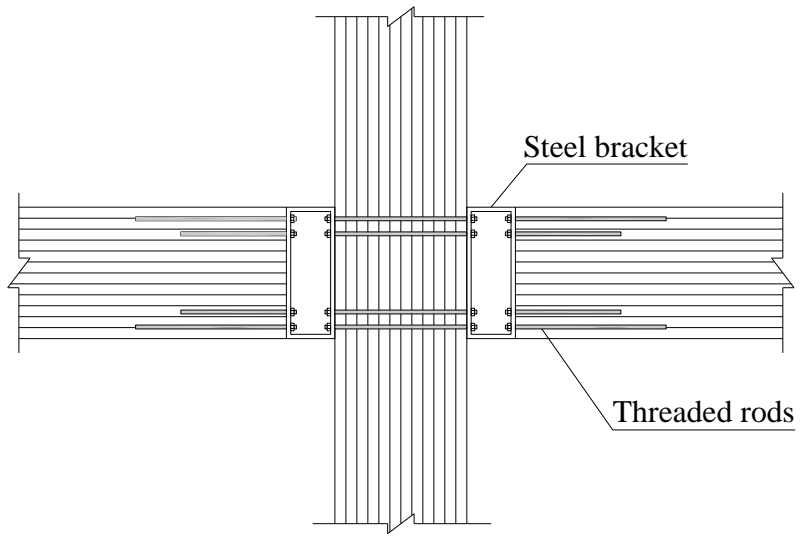

(b) With steel brackets

Fig. 1. Moment-resisting glulam beam-column connections using glued-in rods [10].

By the cyclic tests on the ductile moment-resisting glulam timber connections with glued-in rods, Fairweather [14] obtained the best results for glulam members with glued-in rods epoxied into the end-grain of glulam beams and bolted to ductile steel connecting brackets. Furthermore this ductile damage to the brackets allows inspection and replacement after an earthquake.

On the basis of experimental evaluation, Buchanan et al. [15] suggested that yielding of steel connecting brackets is preferred to yielding of the epoxied rods for ductile seismic design. However, the problem is that tension perpendicular to grain stresses would occur due to the shrinkage of the timber while the beams are bolted to rigid steel brackets at high moisture content. And therefore some measures must to be taken, e.g. by providing transverse steel rods, to prevent the splitting or shear failure at the beam end.

Vašek and Vyhnálek [13] provided the steel component by steel box section to the glued-in 
rod beam-column connections. Furthermore, to prevent the wood splitting failure at the beam end, a vertical connecting rod was introduced between the upper and the lower steel tube. The test work showed a quite positive result in which the strength of connections was similar to that of glulam beam.

Fragiacomo and Batchelar [17,18] provided a design process and long-term experimental investigation on timber frame moment joints with glued-in steel rods. The design method for the connections was based on the use of the transformed section method at the beam-column interface so as to evaluate the stress distribution in the rods and timber. Also the failure type, ductile or brittle, could easily be assessed. However, it was difficult to calculate the stiffness of rotational spring due to the shortage of information about it.

\subsection{Component method}

To investigate the moment-resistant timber joint $\mathrm{M}-\phi$ curve or its characteristic properties of strength, initial rotational stiffness and rotational capacity, the suitable design model is necessary. A possible solution is the introduction of the component method [21,22], which is successfully used in steel and steel-concrete composite connections, into moment-resistant timber connections. The originality of the component method is that it considers any joint as a set of "individual basic components" [21]. Each component is represented by an extensional spring, which is independent and can be connected to other springs or to rigid elements [23]. Once the individual constitutive components are identified and characterized, the overall behaviour of the connection can be modelled through the so-called assembly procedures [24].

Moment-resistant timber connections were investigated using the component method mentioned above in the literatures $[13,19,20,24,25]$. By using the component method, Tomasi et al. [19] and Andreolli et al. [20]. carried out detail investigation on ductile moment-resistant timber connections with the combination of glued-in rods and steel connecting studs. It was discovered that the method could well predict the joint response in 
terms of failure mode, ultimate resistance, stiffness, and rotation capacity.

\subsection{Objectives of the study}

The objective of this research was to develop and validate a theoretical model based on the component method and to predict the strength and stiffness properties of moment-resistant glulam beam-column connections with glued-in rods.

\section{Theoretical model}

\subsection{Model methodology}

In accordance with Jaspart [21] and EN 1993-1-8 [22], a design moment-rotation characteristic should define the following three main structural properties: (a) moment resistance $M_{\mathrm{j}, \mathrm{Rd}}$; (b) initial rotational stiffness $S_{\mathrm{j}, \text { ini }}$; and (c) rotation capacity (maximum rotation at failure) $\phi_{\mathrm{Cd}}$.

Essentially, the application of the component method requires the following steps:

- identification of the active components for the studied joint;

- evaluation of the mechanical characteristics of each individual basic component (specific characteristics — design strength, initial stiffness, etc.);

- "assembly" of the components into a mechanical model made up of extensional springs and rigid links.

\subsection{Basic components of the joint}

In the connection shown in Fig. 2 (a), which is theoretically and experimentally evaluated in this paper, several separate steel box sections are connected with glued-in rods or glued-in steel tube to glulam beam end and with connecting bolts to glulam column. The steel box section of the middle one combined with glued-in steel tube was designed to mainly transfer the shear force and to prevent shear failure of the connection, while the other two steel box sections with glued-in rods were used to transmit the bending moment.

As to the assembling of the connections, the rods and steel tube were firstly glued into the 
holes at the beam end. After the solidification of glue, the glulam beam was connected with glulam column using steel box sections and bolts.

The basic components were depicted in Fig. 2(a) and Fig. 2(b), while the naming of each component was provided in Table 1.

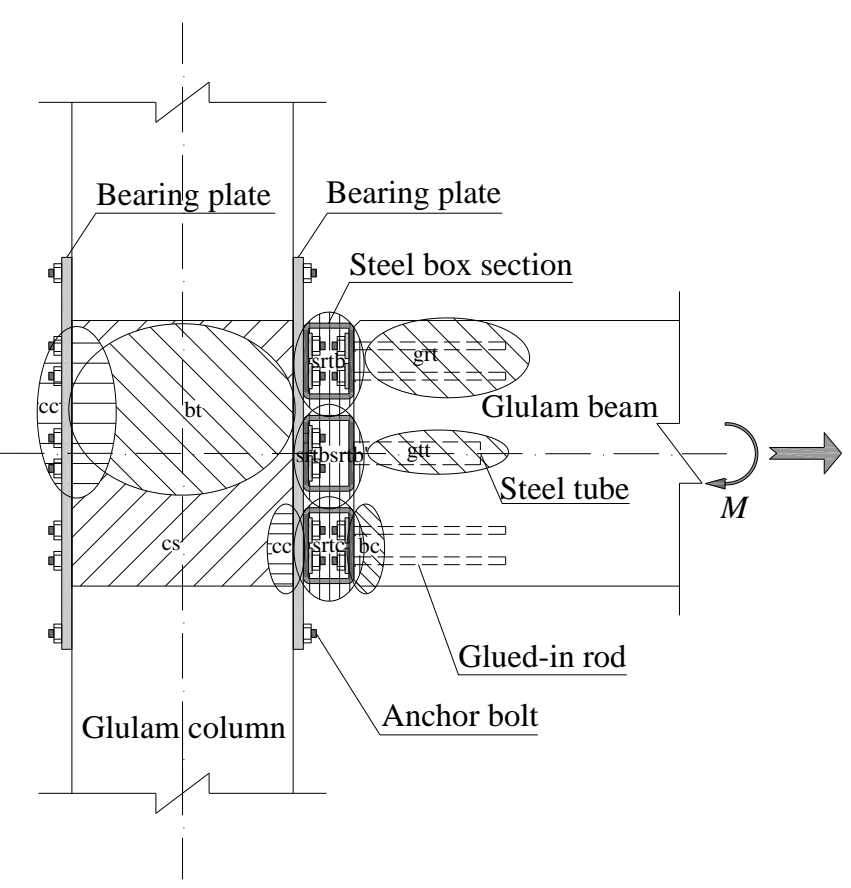

(a) Joint geometry

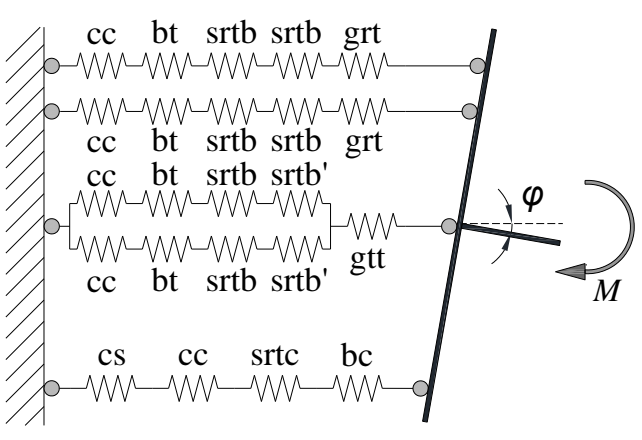

(b) Basic components

Fig. 2. Basic components for glulam beam-column connections.

\section{Table 1}

Naming of the various components used in the mechanical models.

\begin{tabular}{llll}
\hline Component & Abbreviation & Component & Abbreviation \\
\hline Beam in compression & bc & Glued-in tube in tension & gtt \\
Bolts in tension & bt & Steel box section in bending & srtb \\
Column in compression & cc & Steel box section in bending & srtb' $^{\text {a }}$ \\
Column in shear & cs & Steel box section in compression & srtc \\
Glued-in rods in tension & grt & & \\
${ }^{\mathrm{a}}$ under the tension force of glued steel tube. &
\end{tabular}

The T-stub concept was introduced into the context of the resistance of end plate connections by Zoetemeijer [26] and adopted in EN 1993-1-8 [22] for both end plate and steel column flange in bending. To simplify the calculating model of this investigation, the 
steel box section with a transverse web stiffener was transformed into two kind of equivalent T-stubs, as shown in Fig. 3, in which the web element was transformed from tube wall and stiffener, respectively. The interaction between these two T-stubs was neglected. For a steel box section without stiffener, only the equivalent T-stub-1 was effective.

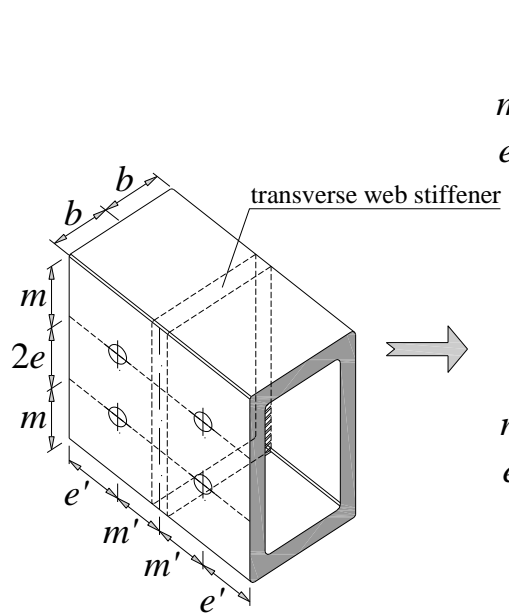

(a) Original tube
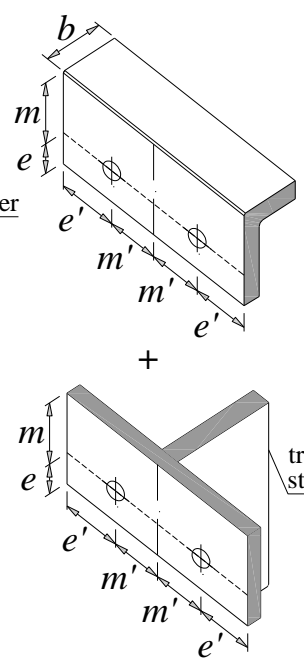

(b) Quarter parts

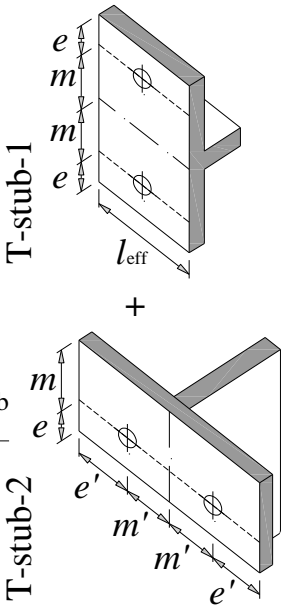

(c) Equivalent T-stub

Fig. 3. Modelling a steel box section as an equivalent T-stub in tension.

\subsection{Mechanical model}

The original mechanical model (see Fig. 4(a)) of component method, which was proposed by Borges [27] and Girão Coelho [28] and referred to as "UC model", was adopted in this paper. According to Fig. 3(a), $k_{\mathrm{i}}$ is the initial elastic stiffness for basic joint component $i$, while $h_{\mathrm{r}}$ is the distance between bolt-row $r$ and the center of compression. The center of compression was assumed to be in line with the center of the compression surface of steel box section.

For UC model [27,28], the components are identical to the ones of EN 1993-1-8 [22] model but they are assembled in a simple way that permits the interaction between tensile and compressive components, as well as between column and connection components [23].

It should be noted that $k_{\text {srtb }}$ or $k_{\text {srtb' }}$ was the sum of the initial elastic stiffness of component T-stub-1 and T-stub-2, as depicted in Fig. 3, since these two spring components were 
connected in parallel.

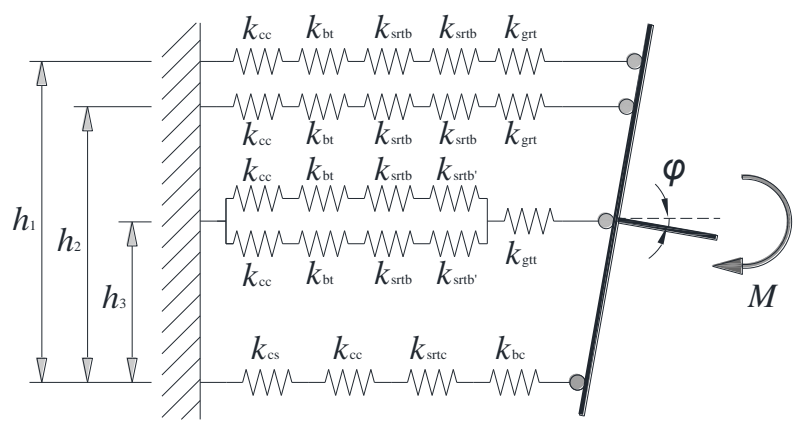

(a) Original model

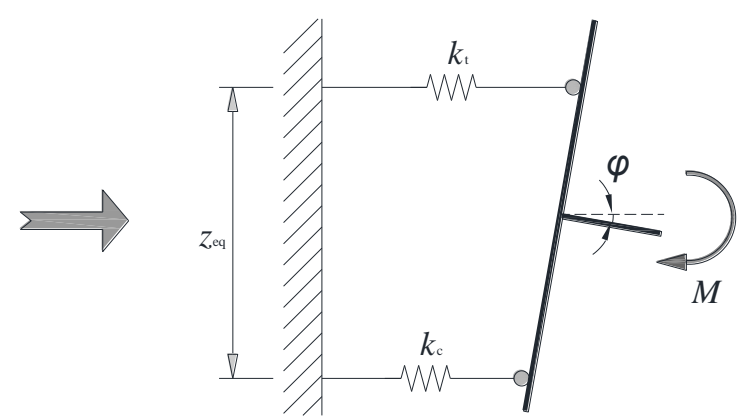

(b) Equivalent model

Fig. 4. Mechanical model for glulam beam-column connections.

According to EN 1993-1-8 [22] and Silva and Coelho [29], the mechanical model depicted in Fig. 4(a) can be further simplified into a substitute model, as illustrated in Fig. 4(b), in which $z_{\text {eq }}$ is the equivalent lever arm, $k_{\mathrm{t}}$ is the equivalent initial elastic stiffness in tension , and $k_{\mathrm{c}}$ is the equivalent initial elastic stiffness in compression/shear.

In accordance with EN 1993-1-8 [22], the equivalent stiffness in tension zone $k_{\mathrm{t}}$ can be determined from Eq. (1):

$k_{t}=\frac{\sum_{r} k_{e f f, r} h_{r}}{z_{e q}}$

where $k_{\text {eff,r }}(\mathrm{kN} / \mathrm{m})$ : the effective stiffness for bolt-row $r$ taking into account the initial elastic stiffness $k_{\mathrm{i}}$ for the basic joint components.

The effective stiffness $k_{\text {eff,r }}$ for bolt-row $r$ should be determined from Eq. (2):

$k_{e f f, r}=\frac{1}{\sum_{i} \frac{1}{k_{i, r}}}$

where $k_{\mathrm{i}, \mathrm{r}}(\mathrm{kN} / \mathrm{m})$ : the initial elastic stiffness representing component $i$ relative to bolt-row $r$.

The equivalent lever arm $z_{\mathrm{eq}}$ should be determined from Eq. (3): 


$$
z_{\text {eq }}=\frac{\sum_{r} k_{e f f, r} h_{r}^{2}}{\sum_{r} k_{e f f, r} h_{r}}
$$

\subsection{Joint moment resistance}

The moment resistance can be determined according to Eq. (4):

$M_{j, R d}=\sum_{r} F_{t r, R d} h_{r}$

where $F_{\mathrm{tr}, \mathrm{Rd}}(\mathrm{kN})$ : the effective tension resistance of bolt-row $r$ of the joint, which should be taken as the smallest value of the design tension resistance from the weakest component relative to bolt-row $r$.

As a conservative simplification, the contribution of the third bolt-row (see Fig. 4(a)) to the moment resistance was neglected. And the ultimate moment resistance was defined as both top two bolt-row reach the tension resistance. Thus Eq. (4) can be replaced with Eq. (5):

$$
M_{j, R d}=F_{t 1, R d} h_{1}+F_{t 2, R d} h_{2}
$$

The value of $F_{\mathrm{t} 1, \mathrm{Rd}}$ or $F_{\mathrm{t} 2, \mathrm{Rd}}$ is the smallest value of:

(a) the resistance of glulam column in shear $F_{\mathrm{t}, \mathrm{cs}, \mathrm{Rd}}$;

(b) the resistance of glulam column in transverse compression $F_{\mathrm{t}, \mathrm{cc}, \mathrm{Rd}}$;

(c) the resistance of bolt in tension $F_{\mathrm{t}, \mathrm{bt}, \mathrm{Rd}}$;

(d) the resistance of steel box section in bending under tension $F_{\mathrm{T}, \mathrm{n}, \mathrm{Rd}}$;

(e) the resistance of steel box section in compression $F_{\mathrm{T}, \mathrm{c}, \mathrm{Rd}}$;

(f) the resistance of glued-in rods in tension $F_{\mathrm{t}, \text { grt,Rd; }}$

(g) the resistance of glulam beam in compression $F_{\mathrm{t}, \mathrm{bc}, \mathrm{Rd} .}$

\subsubsection{Glulam column in shear}

The resistance of glulam column in shear $F_{\mathrm{t}, \mathrm{cs}, \text { Rd }}$ may be determined as Eq. (6).

$$
F_{t, c s, R d}=f_{v} b_{c} l_{v, \text { eff }}
$$

where $f_{\mathrm{v}}\left(\mathrm{N} / \mathrm{mm}^{2}\right)$ : the shear strength of glulam; $b_{\mathrm{c}}(\mathrm{mm})$ : the width of glulam column; $l_{\mathrm{v}, \text { eff }}$ 
$(\mathrm{mm})$ : the effective length of glulam column in shear, here approximately taken as the length of the bearing plates.

\subsubsection{Glulam column in transverse compression}

The compression area of glulam column at surface under the equivalent T-stub is defined according to EN 1993-1-8 [22], in which the transverse compression forces spread uniformly as shown in Fig 5. The additional bearing width $c$ proposed by EN 1993-1-8 [22] for steel connections is adopted here for timber bearing materials and can then be determined according to Eq. (7). Also the forces transferred through the connecting bolts are assumed to be the same as that of a T-stub.

$$
c=t_{b p}\left[f_{y} /\left(3 f_{c u, 90} \gamma_{M 0}\right)\right]^{0.5}
$$

where $t_{\mathrm{bp}}(\mathrm{mm})$ : the thickness of the steel bearing plate; $f_{\mathrm{y}}\left(\mathrm{N} / \mathrm{mm}^{2}\right)$ : the yield strength of the steel bearing plate; $f_{\mathrm{cu}, 90}\left(\mathrm{~N} / \mathrm{mm}^{2}\right)$ : compression strength of glulam perpendicular to grain; $\gamma_{\mathrm{M} 0}$ (dimensionless): the partial safety factor according to EN 1993-1-1 [30].
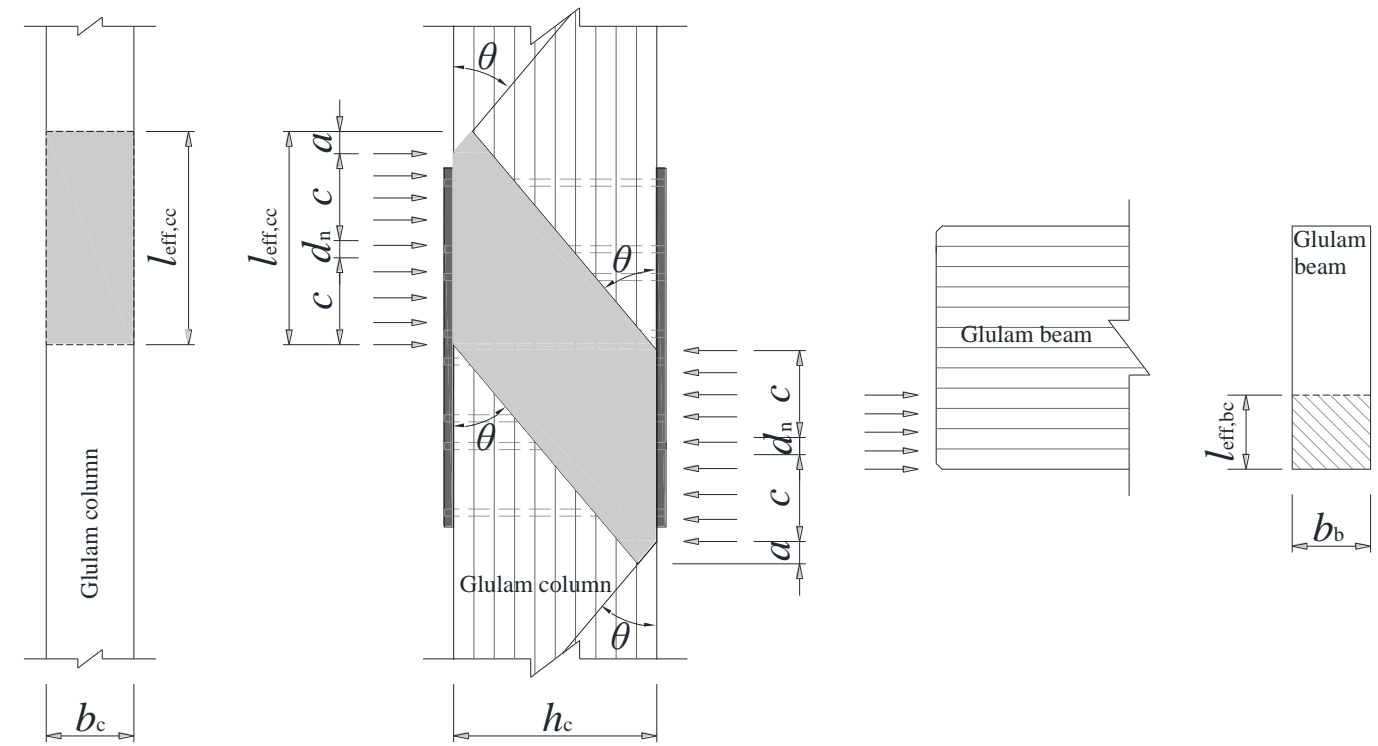

Fig. 5. Compression area of glulam components.

For two sided loaded long wood or glulam blocks in compression perpendicular to grain, according to Van der Put [31], the load will spread with an angle $\theta$ to another side, as depicted in Fig. 5. Furthermore, the angle $\theta$ can be assumed to be $45^{\circ}$ at the elastic stage [31]. 
Thus the distance $a$ in Fig. 5 can be calculated through the geometrical relationships.

Thus the resistance of glulam column in compression $F_{\mathrm{t}, \mathrm{cc}, \mathrm{Rd}}$ may then be determined as Eq. (8).

$$
F_{t, c c, R d}=f_{c u, 90, l} b_{c} l_{e f f, c c}=f_{c u, 90, l} b_{c}\left(2 c+a+d_{n}\right)
$$

where $f_{\mathrm{cu}, 90, l}\left(\mathrm{~N} / \mathrm{mm}^{2}\right)$ : local compression strength of glulam perpendicular to grain under the bearing plate; $l_{\text {eff,cc }}(\mathrm{mm})$ : the effective bearing length of glulam column in compression perpendicular to grain; $d_{\mathrm{n}}(\mathrm{mm})$ : the diameter of the bolt nuts or the width of the washers.

\subsubsection{Bolt in tension}

The resistance of the connecting bolt in tension $F_{\mathrm{t}, \mathrm{bt}, \mathrm{Rd}}$ are determined as Eq. (9).

$$
F_{t, b t, R d}=f_{y} A_{b}
$$

where $f_{\mathrm{y}}\left(\mathrm{N} / \mathrm{mm}^{2}\right)$ : the yield strength of the connecting bolt; $A_{\mathrm{b}}\left(\mathrm{mm}^{2}\right)$ : the cross sectional area of the connecting bolts for a single bolt-row.

\subsubsection{Steel box section in bending under tension}

Since the steel box section was transformed into the equivalent T-stub components, generally there are three main failure modes for it according to EN 1993-1-8 [22] and EN 1993-1-1 [30]: (a) complete flange yielding; (b) bolt failure with flange yielding; (c) bolt failure. Then the tension resistance of the equivalent T-stub should be taken as the smallest value for the three possible failure modes indicated in Fig. 6.

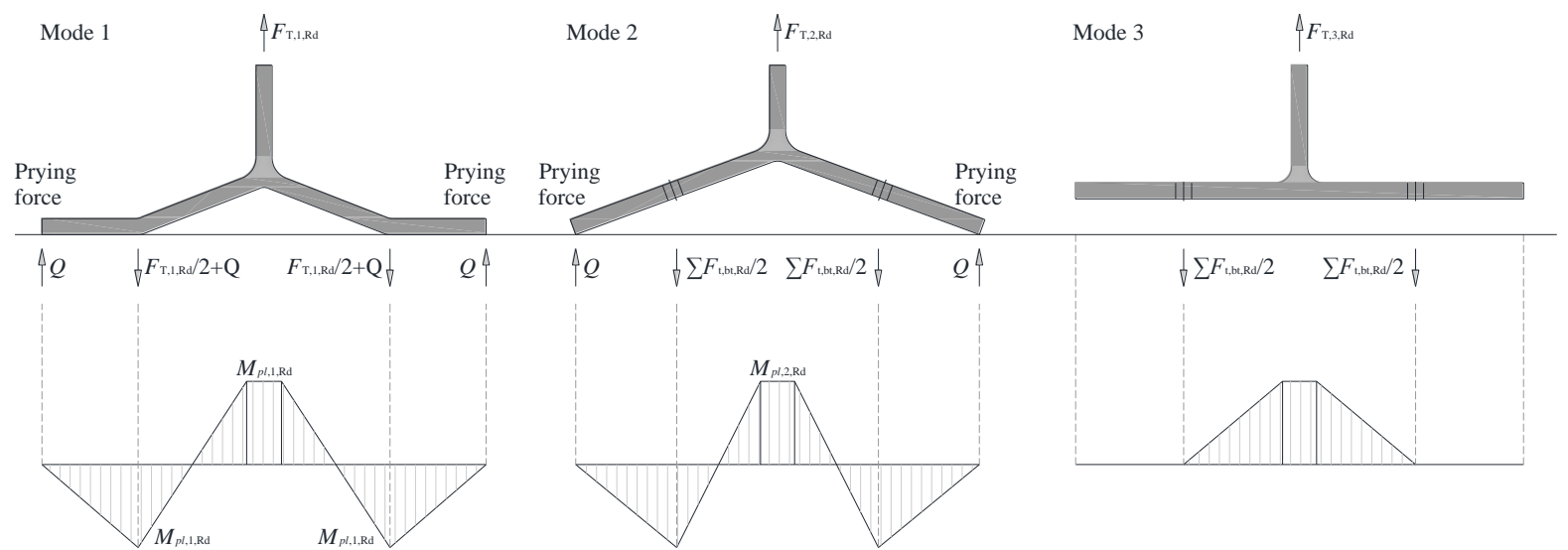

Fig. 6. Failure modes of a T-stub [22,30]. 
The resistance of the equivalent T-stub can then be determined for both with and without prying force of the above failure modes. The first failure mode, in which only equivalent T-stub flange fails, can better satisfy the allowing of the inspection and replacement after an earthquake as well as provide good strength and ductility performance. For this reason, the design of this kind of connection would be better to ensure that the failure occurs in the equivalent T-stub.

The resistance under failure mode 1 of a T-stub flange with prying forces $F_{\mathrm{T}, 1, \mathrm{Rd}}$ can then be determined as Eq. (10) based on EN 1993-1-8 [22].

$F_{T, 1, R d}= \begin{cases}\frac{4 M_{p l, 1, R d}}{m}, & \text { for that without backing plates } \\ \frac{4 M_{p l, 1, R d}+2 M_{b p, R d}}{m}, & \text { for that with backing plates }\end{cases}$

where $M_{p l, 1, \mathrm{Rd}}(\mathrm{Nmm})$ : the moment resistance of the equivalent T-stub flange under failure mode $1 ; M_{b p, \mathrm{Rd}}(\mathrm{Nmm})$ : the moment resistance of the backing plates (herein refers to the washers) under failure mode $1 ; m(\mathrm{~mm})$ : the distance between a hole to the equivalent T-stub web as shown in Fig. 3.

The resistance under failure mode 1 of a T-stub flange without prying forces is 0.5 times that of $F_{\mathrm{T}, 1, \mathrm{Rd}}$.

The moment resistance of the equivalent T-stub flange and the backing plates under failure mode 1 can be calculated as shown in the following equation:

$\begin{cases}M_{p l, 1, R d}=0.25 \sum l_{e f f, 1} t_{f}^{2} f_{u}, & \text { for T-stub flange } \\ M_{b p, R d}=0.25 \sum l_{e f f, 1} t_{b p}^{2} f_{u, b p}, & \text { for backing plates }\end{cases}$

where $\sum l_{\text {eff,1 }}(\mathrm{mm})$ : the value of total effective length for mode 1 of an equivalent T-stub, which can be determined from EN 1993-1-8 [22] for an end-plate; $t_{\mathrm{f}}(\mathrm{mm})$ : the flange thickness of an equivalent T-stub; $t_{\mathrm{bp}}(\mathrm{mm})$ : the backing plate thickness; $f_{\mathrm{u}}\left(\mathrm{N} / \mathrm{mm}^{2}\right)$ : the ultimate strength of the flange of an equivalent T-stub; $f_{\mathrm{u}, \mathrm{bp}}\left(\mathrm{N} / \mathrm{mm}^{2}\right)$ : the ultimate strength of 
the backing plates.

It should be noted that the nominal yield stress $f_{\mathrm{y}}$ has been replaced by the ultimate strength $f_{\mathrm{u}}$ as considering the strain hardening of steel materials [20], which provides a significant part of the ultimate resistance.

For the cases of mode 3 , in which the failure is determined by the resistance of bolts in tension, it is not preferred in this research since it is difficult to replace/repair and cannot provide sufficient plastic rotation.

\subsubsection{Steel box section in compression}

Assuming that the compression forces spread uniformly on the tube surface and the equivalent T-stub flange is simply supported, then the resistance of steel box section in compression $M_{\mathrm{T}, \mathrm{c}, \mathrm{Rd}}$ may be determined as:

$M_{T, c, R d}=f_{u} b_{f} t_{f}^{2} / 6$

where $b_{\mathrm{f}}(\mathrm{mm})$ : the width of equivalent T-stub flange.

\subsubsection{Glued-in rods in tension}

For the same reason detailed above for why the yielding failure of equivalent T-stub flange is preferred, it is strongly recommended to avoid any kind of failure for glued-in rods. Such failure modes may include: (a) yielding of the glued-in rods; (b) failure of adhesive; (c) failure of timber adjacent to the glue line; (d) failure of the timber member. Thus it is assumed that no failure occurs in glued-in rods.

As detailed explained by Jorissen and Fragiacomo [32], to ensure plasticization of the ductile element (the equivalent T-stub flange), an overstrength factor $\left(\gamma_{R d}=1.70\right)$ was adopted herein, which refers to the ratio of the design strength capacity between ductile element and brittle one (glued-in rods joints).

\subsubsection{Glulam beam in compression}

The resistance of glulam beam in compression can be determined as: 
$F_{t, b c, R d}=f_{c u, 0} b_{b} l_{e f f, b c}=0.5 f_{c u, 0} b_{b} h_{s r t}$

where $f_{\mathrm{cu}, 0}\left(\mathrm{~N} / \mathrm{mm}^{2}\right)$ : the compression strength of glulam beam in parallel to grain direction; $b_{\mathrm{b}}(\mathrm{mm})$ : the width of glulam beam; $l_{\mathrm{eff}, \mathrm{bc}}(\mathrm{mm})$ : the effective bearing length of glulam beam in compression parallel to grain, which can be taken as $0.5 h_{\text {srt }} ; h_{\text {srt }}(\mathrm{mm})$ : the cross-sectional depth of the steel tube.

\subsection{Joint initial rotational stiffness}

The initial rotational stiffness $S_{\mathrm{j}, \text { ini }}$ should be determined according to EN 1993-1-8 [22] as shown in the following equation.

$$
S_{j, i n i}=\frac{z_{e q}^{2}}{1 / k_{t}+1 / k_{c}}
$$

where $z_{\mathrm{eq}}(\mathrm{m})$ : the equivalent lever arm as shown in Fig. $4(\mathrm{~b}) ; k_{\mathrm{t}}(\mathrm{kN} / \mathrm{m})$ : the equivalent stiffness in tension zone as provided in Eq. (1) and shown in Fig. 4(b); $k_{\mathrm{c}}(\mathrm{kN} / \mathrm{m})$ : the equivalent stiffness in compression/shear zone, as defined as:

$$
k_{c}=\frac{1}{1 / k_{c s}+1 / k_{c c}+1 / k_{s r t c}+1 / k_{b c}}
$$

To obtain the initial rotational stiffness $S_{\mathrm{j}, \text { ini }}$, it requires the initial elastic stiffness of the basic joint component $k_{\mathrm{i}}$, which is presented in detail in the following.

The effective length in compression for glulam column has been taken as $2 c+a+d_{\mathrm{n}}$, as shown in Fig. 5. Thus the stiffness for glulam column in transverse compression $k_{\mathrm{cc}}$ becomes:

$$
k_{c c}=\frac{E_{w, 90, l} b_{c} l_{e f f, c c}}{h_{c}}=\frac{E_{w, 90, l} b_{c}\left(2 c+a+d_{n}\right)}{h_{c}}
$$

where $E_{\mathrm{w}, 90, l}\left(\mathrm{~N} / \mathrm{mm}^{2}\right)$ : local modulus of elasticity perpendicular to grain of glulam column; $h_{\mathrm{c}}$ (mm): the depth of glulam column.

According to Tomasi et al. [19], the stiffness for glulam beam in compression $k_{\mathrm{bc}}$ can be determined using Eq. (17). 
$k_{b c}=\frac{E_{w, 0} \sqrt{b_{b}\left(m+e+c^{\prime}\right)}}{\beta}$

where $E_{\mathrm{w}, 0}\left(\mathrm{~N} / \mathrm{mm}^{2}\right)$ : modulus of elasticity parallel to grain of glulam beam; $\beta$ (dimensionless): coefficient, which can be approximated to the value 4 [19].

The stiffness for glulam column in shear $k_{\mathrm{cs}}$ can be determined using Eq. (18) on the basis of classic mechanics theory for a short column.

$k_{c s}=\frac{G_{w} A_{c}}{z_{e q}}=\frac{G_{w} b_{c} h_{c}}{z_{e q}}$

where $G_{\mathrm{w}}\left(\mathrm{N} / \mathrm{mm}^{2}\right)$ : shear modulus of glulam column; $A_{\mathrm{c}}\left(\mathrm{mm}^{2}\right)$ : cross sectional area of glulam column.

The stiffness for bolt in tension $k_{\mathrm{bt}}$ can also be determined according to classic mechanics theory as Eq. (19).

$k_{b t}=\frac{E_{b} A_{b t}}{l_{b t}}$

where $E_{\mathrm{b}}\left(\mathrm{N} / \mathrm{mm}^{2}\right)$ : modulus of elasticity of bolts; $A_{\mathrm{bt}}\left(\mathrm{mm}^{2}\right)$ : cross sectional area of bolts for single bolt-row; $l_{\mathrm{bt}}(\mathrm{mm})$ : length of bolts between the nuts on both ends.

In accordance with EN 1993-1-8 [22], the stiffness for end-plate in bending under tension (for a single bolt-row in tension) $k_{\mathrm{stb}}$ is:

(a) with prying forces:

$k_{s r t b}=\frac{0.85 E_{s} l_{\text {eff }} t_{f}^{3}}{m^{3}}$

(b) without prying forces:

$k_{s r t b}=\frac{0.425 E_{s} l_{e f f} t_{f}^{3}}{m^{3}}$

where $E_{\mathrm{s}}\left(\mathrm{N} / \mathrm{mm}^{2}\right)$ : modulus of elasticity of steel box section; $l_{\text {eff }}(\mathrm{mm})$ : the effective length of the equivalent T-stub flange [22]. 
To simplify the calculation, the stiffness for end-plate in bending under tension due to the middle steel tube $k_{\text {srtb' }}$ is considered identical to $k_{\text {srtb }}$.

The stiffness for glued-in rod in tension $k_{\text {grt }}$ was defined in EN 1993-1-8 [22] as an anchor bolt as seen in following equation:

(a) with prying forces:

$k_{g r t}=\frac{1.6 E_{g r} A_{g r}}{L_{b}}$

(b) without prying forces:

$k_{g r t}=\frac{2.0 E_{g r} A_{g r}}{L_{b}}$

where $E_{\mathrm{gr}}\left(\mathrm{N} / \mathrm{mm}^{2}\right)$ : modulus of elasticity of glued-in rod; $A_{\mathrm{gr}}\left(\mathrm{mm}^{2}\right)$ : cross sectional area of glued-in rods for a single bolt-row; $L_{\mathrm{b}}(\mathrm{mm})$ : the glued-in rod elongation length, which is determined as Eq. (24).

$L_{b}=\alpha \Phi_{g r}$

where $\alpha$ (dimensionless): coefficient, which was proposed by Tomasi et al. [19] taking into account the Volkersen analysis of a single lap joint [33], as indicated in Eq. (25); $\Phi_{\mathrm{gr}}(\mathrm{mm})$ : the diameter of a glued-in rod.

$1 / \alpha=\left(1+\frac{E_{g r}}{45.8 E_{w, 0}}\right) \Phi_{g r} \cdot \sqrt{\left(1+\frac{E_{g r}}{45.8 E_{w, 0}}\right) \cdot \frac{G_{a} \pi \Phi_{g r}}{E_{g r} A_{g r, s} t_{a}}}$

where $G_{\mathrm{a}}\left(\mathrm{N} / \mathrm{mm}^{2}\right)$ : shear modulus of the adhesive; $A_{\mathrm{gr}, \mathrm{s}}\left(\mathrm{mm}^{2}\right)$ : cross sectional area of a single glued-in rod; $t_{\mathrm{a}}(\mathrm{mm})$ : the glue-line thickness.

The stiffness for glued-in steel tube in tension $k_{\mathrm{gtt}}$ was defined using the same method as that of glued-in rods.

For steel box section without stiffener in compression, the initial stiffness $k_{\text {srtc }}$ can be determined approximately as Eq. (26), which is based on the assumption of the simply supported beam theory for the equivalent T-stub flange. 
$k_{s r t c}=\frac{32 E_{s} b_{s r t} t_{f}^{3}}{h_{s r t}^{3}}$

where $E_{\mathrm{s}}\left(\mathrm{N} / \mathrm{mm}^{2}\right)$ : modulus of elasticity of steel box section; $b_{\text {srt }}(\mathrm{mm})$ : the cross-sectional width of the steel tube; $h_{\text {srt }}(\mathrm{mm})$ : the cross-sectional depth of the steel tube.

For steel box section with stiffener, the initial stiffness in compression is assumed to be infinite.

\subsection{Joint rotational capacity}

The joint rotation capacity is primarily determined by the deformation capacity of the component with the lowest strength, here in this investigate $F_{\mathrm{T}, 1, \mathrm{Rd}}$ the steel box section in bending under tension is preferred to be the weakest component. Therefore steel box section in bending under tension contributes its full deformation capacity, while the other components with the deformations at the stress level corresponding to that strength [34].

At the ultimate rotation limit state, assuming that the equivalent T-stub in bending under tension for the outmost two bolt-rows in tension zone both reach the ultimate displacements $\delta_{\mathrm{u}, \mathrm{T}, 1}$, which was proposed by Beg et al. [34] for Mode 1 failure and provided as Eq. (27). Since the contribution to the joint rotation of the components of the two middle bolt-rows is quite smaller than the others, it can be neglected then. Thus the applied forces on the concerned bolt-rows may be given as illustrated in Fig. 7 .

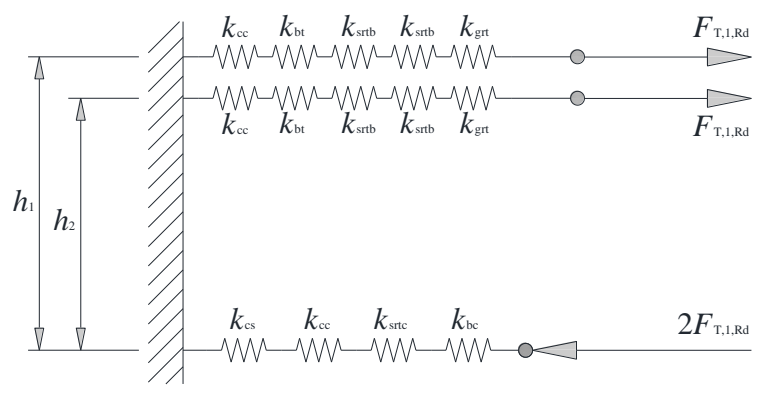

Fig. 7. Simplified spring components.

$\delta_{u, T, 1}=2 \varepsilon_{u} m$

where $\varepsilon_{\mathrm{u}}$ (dimensionless): the ultimate strain at the outer surface of the equivalent T-stub 
flange in bending, which can be taken as 0.30 from the experimental work upon the steel box section of this research.

Provided the force-displacement relationships of the spring components, the force-deformation and $M-\phi$ curves of the entire joint can be obtained under the applied load as depicted in Fig. 7. For this purpose, a simplified force-displacement curves of steel components can be defined as shown in Fig. 8(a), which was proposed by Beg et al. [34] on the basis of EN 1993-1-8 [22]. Generally for wood components in compression, a non-linear relationship (elastic-plastic) may be used for its force-displacement or stress-strain curves as depicted in Fig 8(b) [35], while for wood components in tension or shear, linear elastic behavior is adopted. $F_{\mathrm{Rd}, \mathrm{i}}, k_{\mathrm{i}}$ and $\delta_{\mathrm{u}, \mathrm{i}}$ is the strength, initial elastic stiffness and the deformation capacity for component $i$, respectively.

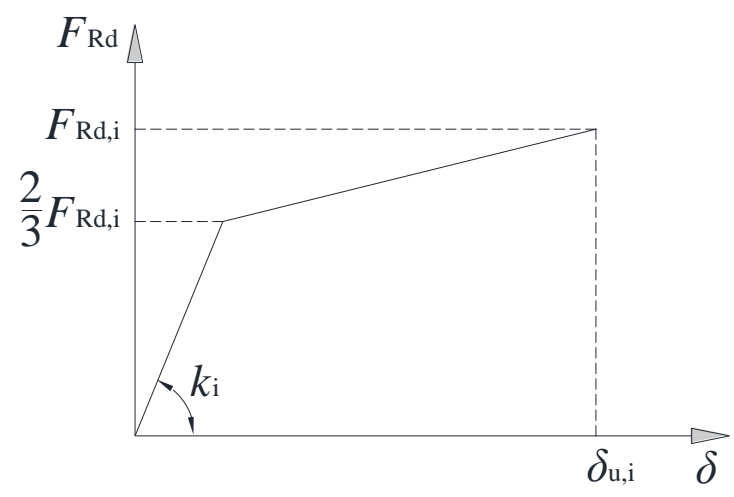

(a) Steel components

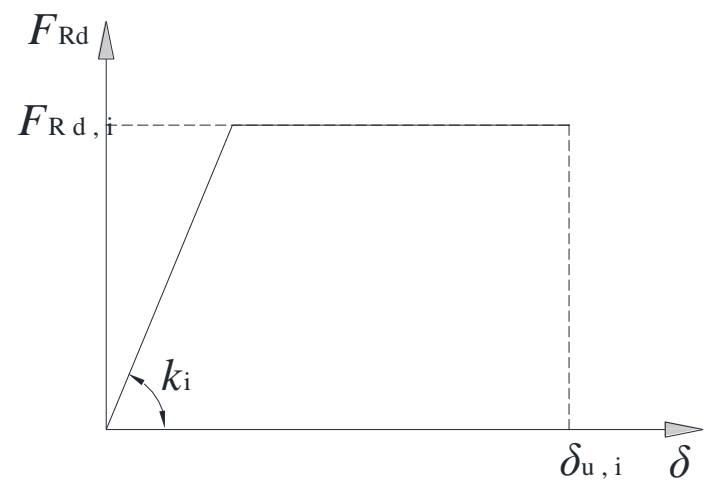

(b) Wood components

Fig. 8. Simplified force-displacement curves of components.

The total deformation of the components in the first bolt-row under the applied tension load $F_{\mathrm{T}, 1, \mathrm{Rd}}$ can be determined by Eq. (28).

$\delta_{t}=\delta_{c c, t}+\delta_{b t}+2 \delta_{u, T, 1}+\delta_{g r t}$

where $\delta_{\mathrm{cc}, \mathrm{t}}, \delta_{\mathrm{bt}}$, and $\delta_{\mathrm{grt}}$ is the deformation of glulam column in compression, bolts in tension and glued-in rods in tension of the tension zone, respectively.

While the total deformation of the components in the compression zone under the applied 
compression load $2 F_{\mathrm{T}, 1, \mathrm{Rd}}$ can be determined by Eq. (29).

$\delta_{c}=\delta_{c c, c}+\delta_{c s}+\delta_{s t c}+\delta_{b c}$

where $\delta_{\mathrm{cc}, \mathrm{c}}, \delta_{\mathrm{cs}}, \delta_{\mathrm{stc}}$, and $\delta_{\mathrm{bc}}$ is the deformation of glulam column in compression, glulam column in shear, steel box section in compression, and glulam beam in compression of the compression zone, respectively.

Thus the joint rotation capacity $\phi_{\mathrm{Cd}}$ can be defined as:

$\phi_{C d}=\frac{\delta_{t, \max }+\delta_{c, \max }}{h_{1}}$

where $\delta_{\mathrm{t}, \max }$ and $\delta_{\mathrm{c}, \max }$ is the maximum deformation at the first bolt-row and at the center of compression zone, respectively.

\section{Validation of analytical model through experimental results}

\subsection{Equivalent T-stub components}

The steel box section was transformed into equivalent T-stub in this investigation. To validate the effectiveness of the substitute T-stub component, two series (T1 series without stiffener and T2 series with a stiffener) of the steel box section (without backing plates) illustrated in Fig. 2(a) were tested under monotonic tensile load till failure. Both the thickness of tube wall and stiffener $t_{\mathrm{f}}$ were $6 \mathrm{~mm}$, while the cross-sectional sizes of $120 \mathrm{~mm} \times 80 \mathrm{~mm}$ with the length of $135 \mathrm{~mm}$. According to Fig. 3, the main geometrical parameters of the steel box section were provided, in which $m=36 \mathrm{~mm}, e=24 \mathrm{~mm}, m^{\prime}=31.5 \mathrm{~mm}$, and $e^{\prime}=36 \mathrm{~mm}$. The sizes of the rectangular washers (backing plates) under the nuts were $67.5 \mathrm{~mm} \times 40 \mathrm{~mm} \times 6$ $\mathrm{mm}$.

Steel plates were characterized as grade S235 with the modulus of elasticity $E_{\mathrm{s}}=200 \mathrm{GPa}$, the nominal yield stress $f_{\mathrm{y}}=310 \mathrm{MPa}$ and the ultimate strength $f_{\mathrm{u}}=420 \mathrm{MPa}$, which were furnished by the supplier.

The loading rate was set to $3.0 \mathrm{~mm} / \mathrm{min}$ and was held constant until failure. 
Fig. 9 illustrates the load conditions of steel box section and the substitute spring components. Fig. 10 represents the load-deformation curves of the two series of steel box sections, in which it can be seen that the ultimate load and stiffness was significantly increased due to the addition of a stiffener. For the failure mode, after the completely yielding of the steel box sections, tearing out failure occurred, as shown in Fig. 11 for T2 series.

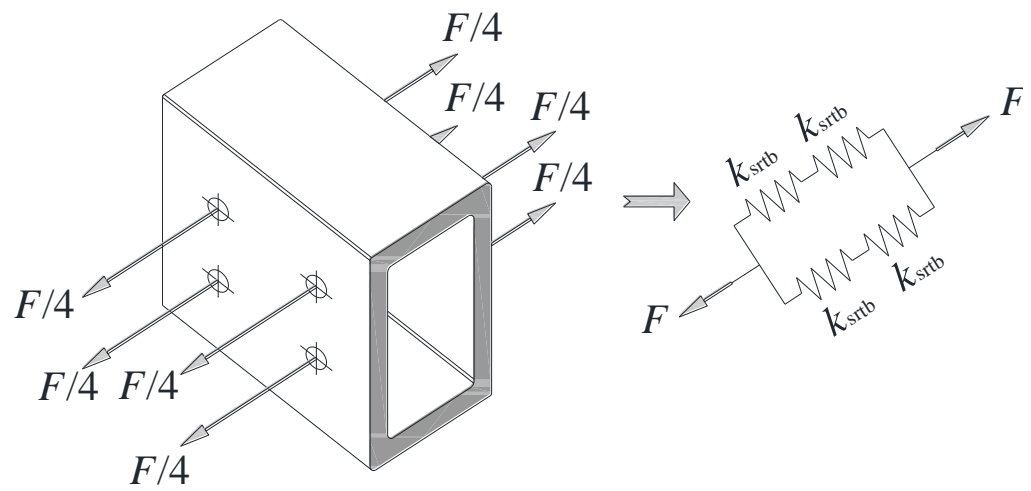

Fig. 9. Load conditions of steel box section and the substitute spring components.

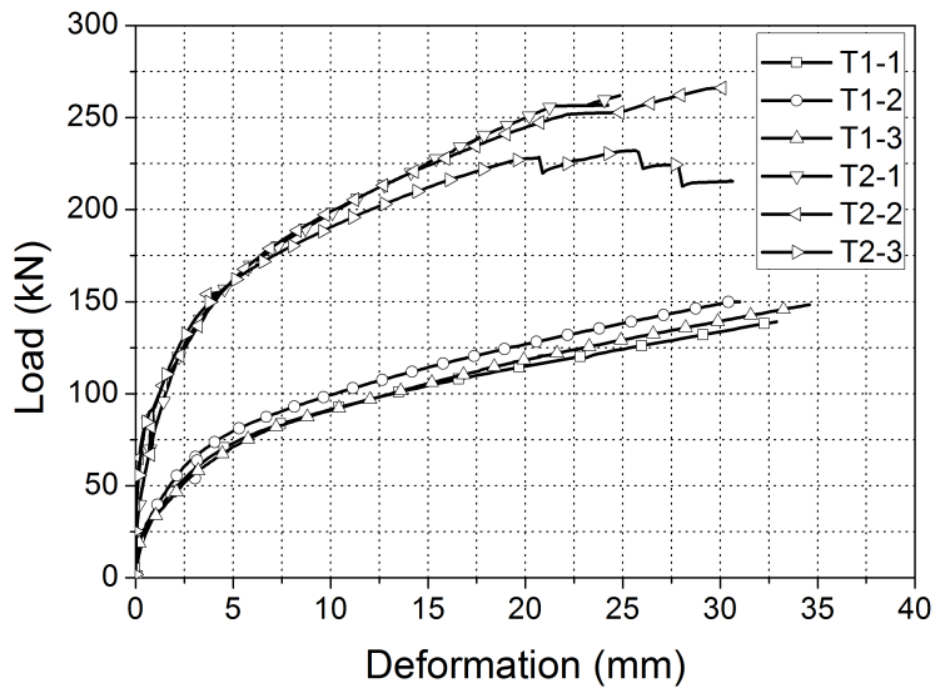

Fig. 10. Load-deformation curves of steel box sections.

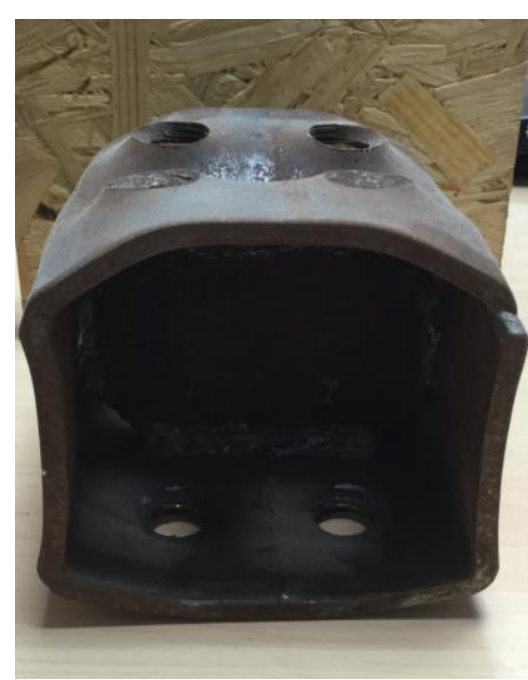

Fig. 11. Typical failure mode.

Table 2

Comparison between theoretical and experimental behavior of an equivalent T-stub.

\begin{tabular}{llllllll}
\hline \multirow{2}{*}{$\begin{array}{l}\text { Series } \\
\text { reference }\end{array}$} & \multicolumn{3}{l}{ Tension resistance $F_{\mathrm{t}, \mathrm{Rd}}(\mathrm{kN})$} & & \multicolumn{3}{l}{ Initial elastic stiffness $k_{\mathrm{e}}(\mathrm{kN} / \mathrm{mm})$} \\
\cline { 2 - 3 } & $\begin{array}{l}\text { Experimental } \\
\text { results }\end{array}$ & $\begin{array}{l}\text { Analytical } \\
\text { results }\end{array}$ & $\begin{array}{l}\text { Difference } \\
(\%)\end{array}$ & & $\begin{array}{l}\text { Experimental } \\
\text { results }\end{array}$ & $\begin{array}{l}\text { Analytical } \\
\text { results }\end{array}$ & $\begin{array}{l}\text { Difference } \\
(\%)\end{array}$ \\
\hline $\mathrm{T} 1$ & 72.9 & 66.2 & -9.2 & & 85.6 & 83.2 & -2.8 \\
$\mathrm{~T} 2$ & 126.7 & 121.0 & -4.5 & & 191.8 & 157.2 & -18.0 \\
\hline
\end{tabular}


Also the comparison on the tension resistance and initial elastic stiffness of the equivalent T-stub is presented in Table 2. It can be seen from Table 2 that the analytical values agree quite well with the experimental mean ones, which proved the high validity of the substitute T-stub model for both with and without stiffener of the steel box sections.

\subsection{Joint moment resistance}

\subsubsection{Materials}

The cross section of beam and column was $135 \mathrm{~mm} \times 420 \mathrm{~mm}$ and $151 \mathrm{~mm} \times 350 \mathrm{~mm}$, respectively (see Fig. 12). The species of timber used in this investigation was North America Douglas fir with No.2 grade in accordance with BS EN 338 [36]. The mechanical properties in mean value (except that $G_{w}$ were provided by BS EN 1194 [37] with the grade of GL36h) directly from test results in accordance with BS EN 408 [38] were shown in Table 3. And the average moisture content of the glulam was $15.0 \%$ with a standard deviation of 0.70 , while the average density was $530 \mathrm{~kg} / \mathrm{m}^{3}$ with a standard deviation of 20.0 .
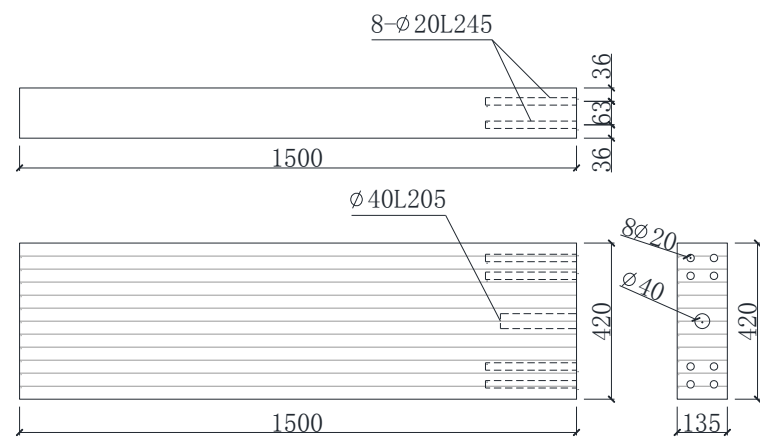

(a) Beam configurations

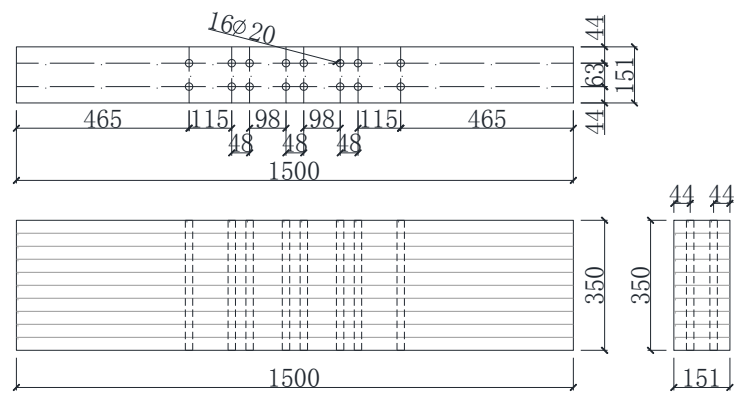

(b) Column configurations

Fig. 12. Beam and column configurations.

The bolt and glued-in rods were grade 8.8 with the yielding strength of $640 \mathrm{MPa}$ and ultimate strength of $800 \mathrm{MPa}$, which were furnished by the supplier. While the grade of the glued-in steel tube for resisting shear force was S235. Moreover, the grade of the backing plates and bearing plates were all S235.

\section{Table 3}


Strength and stiffness properties of homogeneous glulam.

\begin{tabular}{ll}
\hline Material property & Value (MPa) \\
\hline Tension strength parallel to grain $f_{t u, 0}$ & 42.2 \\
Compression strength parallel to grain $f_{c u, 0}$ & 45.6 \\
Local compression strength perpendicular to grain $f_{c u, 90, l}$ & 9.0 \\
Modulus of elasticity parallel to grain $E_{w, 0}$ & 12,500 \\
Local modulus of elasticity perpendicular to grain $E_{w, 90, l}$ & 900 \\
Shear strength parallel to grain $f_{v}$ & 9.3 \\
Shear modulus $G_{w}$ & 910 \\
\hline
\end{tabular}

Two-component epoxy resin with the density of about $1,500 \mathrm{~kg} / \mathrm{m}^{3}$ and glue-line thickness of $2.0 \mathrm{~mm}$, was used to bond the rods to glulam beams in this research. The mechanical properties are furnished by the manufacturer and listed in Table 4.

\section{Table 4}

Physical and mechanical properties of the epoxy resin.

\begin{tabular}{ll}
\hline Properties & Value \\
\hline Specific gravity of mix $\left(\mathrm{kg} / \mathrm{m}^{3}\right)$ & 1500 \\
Compressive strength $(\mathrm{MPa})$ & 84.3 \\
Tensile bending strength $(\mathrm{MPa})$ & 92.7 \\
Splitting strength (MPa) & 14.5 \\
Steel-to-steel Shear strength (MPa) & 22.0 \\
Tensile modulus of elasticity (MPa) & $>2800$ \\
Shear modulus (MPa) & 1500 \\
\hline
\end{tabular}

\subsubsection{Specimen preparation and experimental program}

Holes in glulam beams and columns were manually drilled parallel to the grain. Glued-in rods were cleaned with acetone to remove dirt and grease from the surface before gluing. Epoxy resin adhesive was injected into the pre-drilled holes from the bottom to approximately $2 / 3$ of the volume of the holes using adhesive gun. The cleaned rods were then inserted into the partially filled holes slowly and rotated until they reached the predetermined location. All specimens were left for curing and conditioning for 7 days before testing.

The loading rate of the monotonic test is $6 \mathrm{~mm} / \mathrm{min}$, while the cyclic test protocols are 
according to ISO 16670 [39] and under displacement control, as shown in Fig. 13.

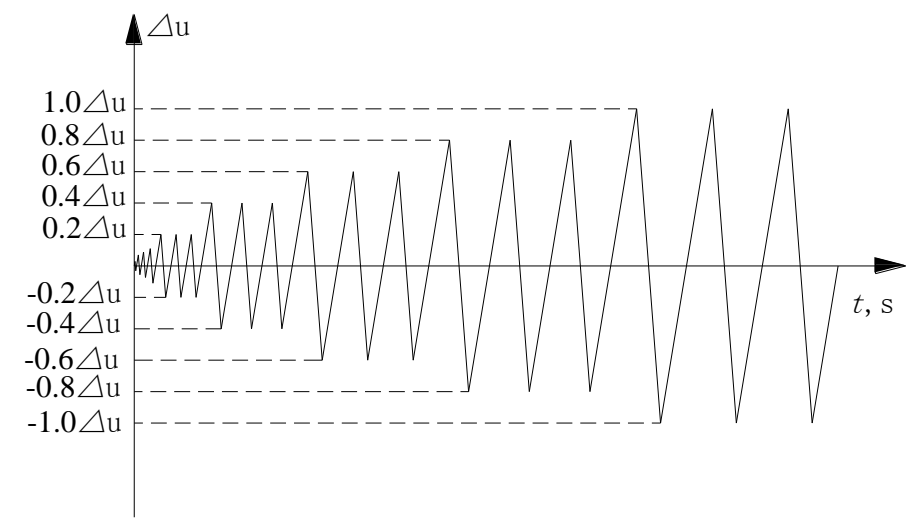

Fig. 13. Cyclic test procedures according to ISO 16670 [39].

\subsubsection{Typical experimental results}

Two series of glulam beam-column joint specimens were tested and three replicate specimens were designed in each series, in which one specimen was tested under monotonic load and the other two under cyclic load. Glulam beam-column joint specimens at both the beginning and the end of experiment were shown in Fig. 14(a) and Fig. 14(b). And it can be seen from Fig. 14(b) that obvious yielding of the equivalent T-stub (with backing plates) of the first two bolt-rows occurred, which well verified the assumption of the theoretical analysis for moment resistance as well as rotational capacity.

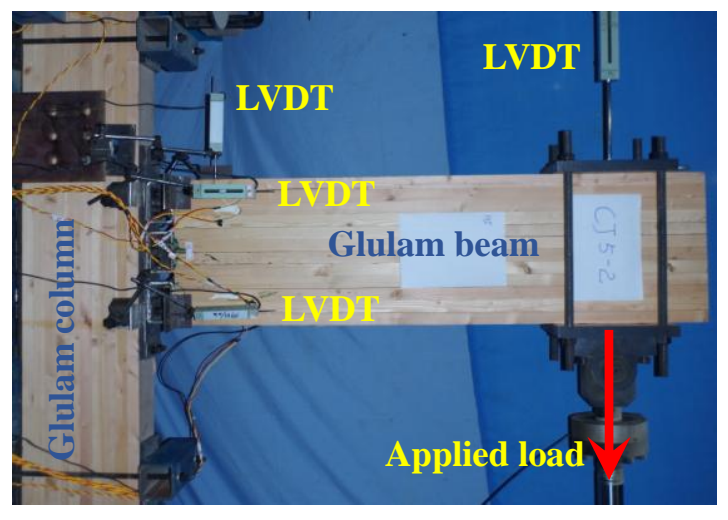

(a) At the beginning of experiment

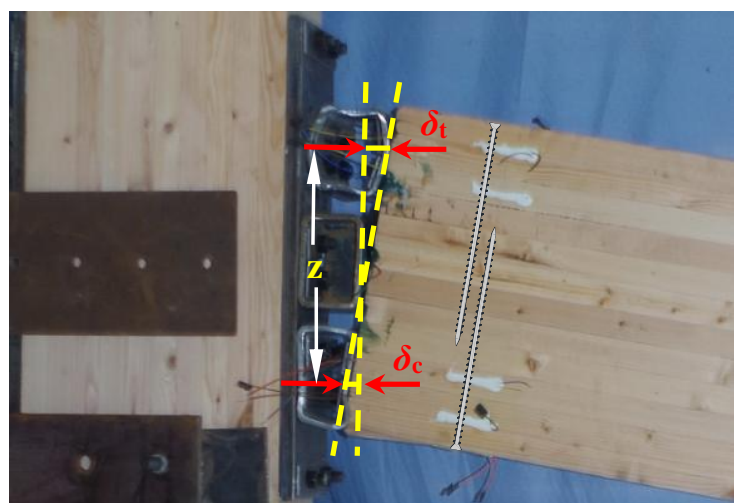

(b) At the end of experiment

Fig. 14. Glulam beam-column joint specimens.

All of the specimens exhibited reasonable ductility. The load-displacement curves is shown in Fig. 15. The pinched shape of the hysteresis loops is primarily due to slop resulting from 
yielding of the glulam under the steel box sections or bearing plates. The transverse web stiffener proved to have remarkable influence on the joint load bearing capacity, stiffness and the ductility, as can be seen from Fig. 15.

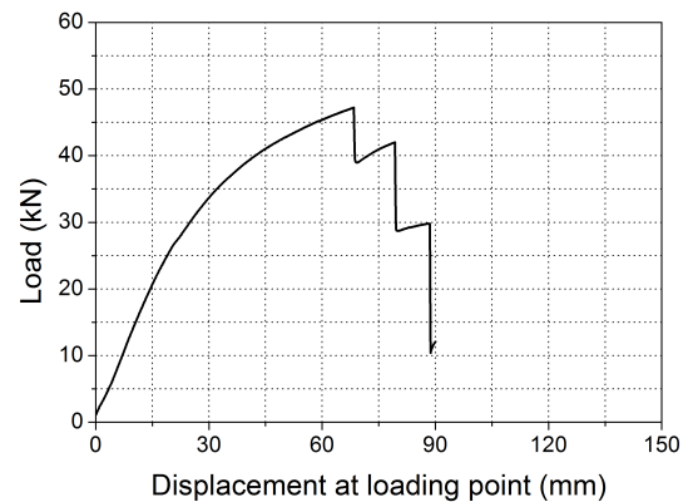

(a) Load-displacement curves of JT2-1

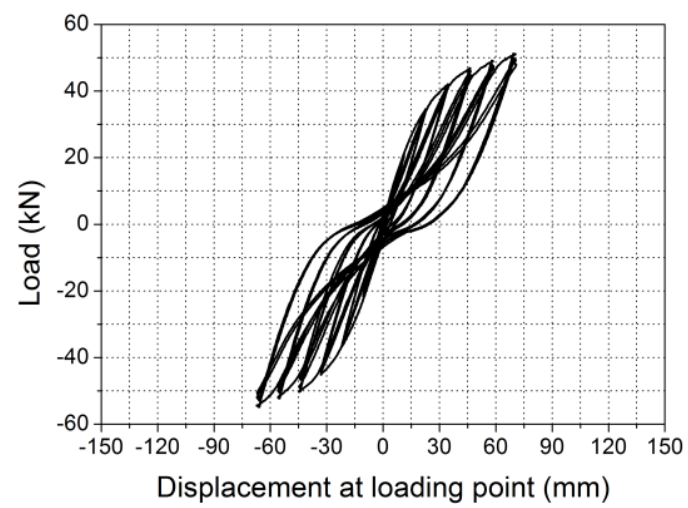

(c) Hysteresis loops of JT2-2

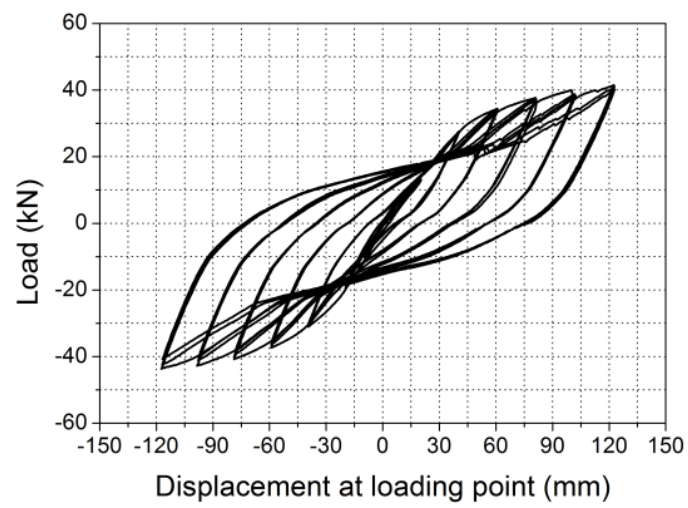

(e) Hysteresis loops of JT3-2

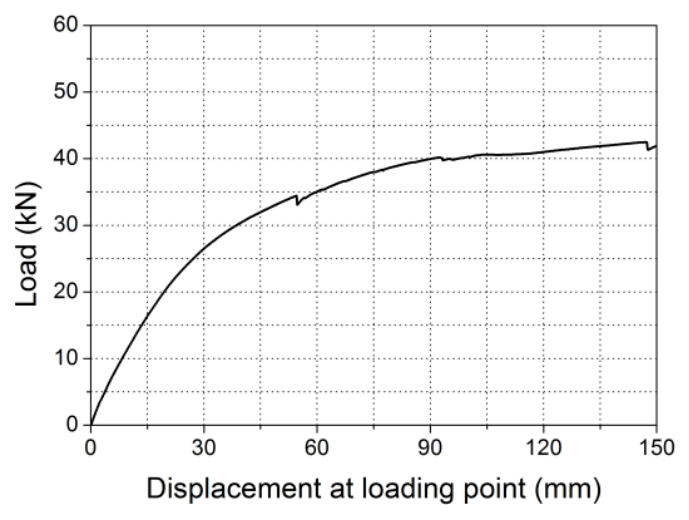

(b) Load-displacement curves of JT3-1

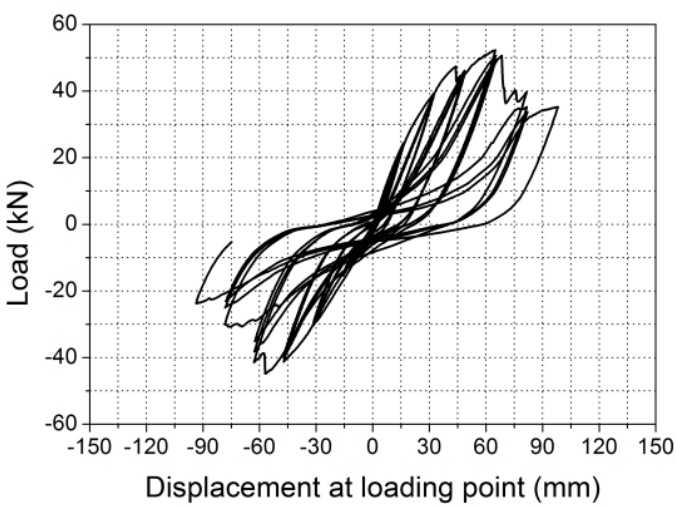

(d) Hysteresis loops of JT2-3

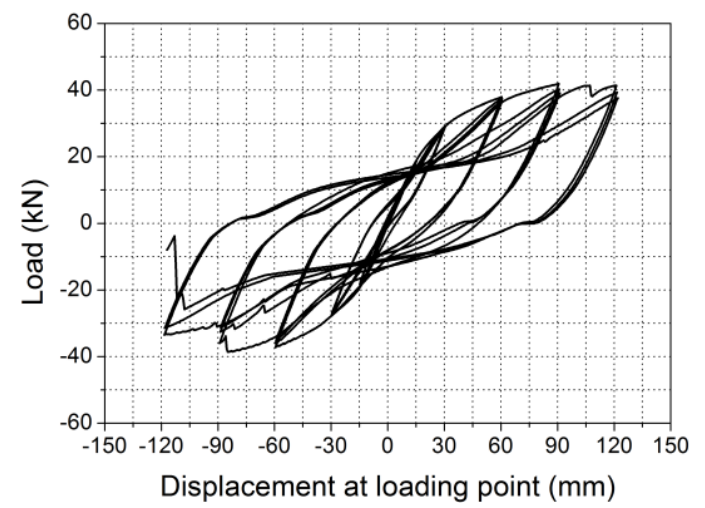

(f) Hysteresis loops of JT3-3

Fig. 15. Load-displacement curves of glulam beam-column joint specimens.

The average ductility factor of JT2 and JT3 series is 2.7 and 4.4, respectively. This 
indicates a satisfactory ductility for this kind of joints.

\subsubsection{Comparison between theoretical and experimental joint moment resistance}

The comparison of joint moment resistant between experimental mean values and the theoretical values by Eq. (5) were executed, as provided in Table 5. As indicated in Table 5, the theoretical values of the joint moment resistant agreed well with that of experimental ones and the theoretical results proved to be a little conservative.

\section{Table 5}

Comparison between theoretical and experimental joint moment resistant.

\begin{tabular}{lllllll}
\hline \multirow{2}{*}{$\begin{array}{l}\text { Series } \\
\text { reference }\end{array}$} & $\begin{array}{l}\text { No. of } \\
\text { replicates }\end{array}$ & $\begin{array}{l}t_{\mathrm{f}} \\
(\mathrm{mm})\end{array}$ & Stiffening & \multicolumn{3}{c}{ Joint moment resistance $M_{j, \mathrm{Rd}}(\mathrm{kNm})$} \\
\cline { 5 - 7 } & & $\begin{array}{l}\text { Experimental } \\
\text { results }\end{array}$ & $\begin{array}{l}\text { Analytical } \\
\text { results }\end{array}$ & $\begin{array}{l}\text { Difference } \\
(\%)\end{array}$ \\
\hline JT2 & 3 & 6 & Yes & 64.1 & 54.1 & -15.6 \\
JT3 & 3 & 8 & No & 54.6 & 51.8 & -5.1 \\
\hline
\end{tabular}

Note: 1 . The steel box section has a cross-sectional size of $120 \mathrm{~mm} \times 80 \mathrm{~mm}$ and the length of $135 \mathrm{~mm}$.

2. The thickness of the stiffener of the steel box section for JT2 is $6 \mathrm{~mm}$, and the location is as shown in Fig. 3 .

It is worth mentioning that, in order to prevent the splitting failure at the beam end, it was introduced into a total of four self-tapping screws with diameter of $8.2 \mathrm{~mm}$ and length of 300 mm (WT-T-8.2 $\times 300$, see Fig. 14(b)) in the transverse direction.

It can be found from Fig. 14(b) that occurred a premature local compressive yielding at the compression face of the glulam beam, which should be prevented in designing and application.

\subsection{Joint initial stiffness}

The initial elastic stiffness values of the components can be calculated from Eqs. (16-26) were illustrated in Fig. 16(a), while the equivalent stiffness value in both tension and compression can be obtained using Eq. (1) and Eq. (15), which is depicted in Fig. 16(b). For those spring components with two values, the former one and latter one represents JT2 series and JT3 series, respectively. Also it can be seen from Table 6 the detailed illustration of the initial elastic stiffness of joint components. 
It is possible from Fig. 16(a) and Table 6 to see that the joint initial rotational stiffness mainly depends on $k_{\mathrm{cc}}, k_{\mathrm{cs}}$ and $k_{\mathrm{srtc}}$, which are relative lower than the others. While the initial elastic stiffness of glued-in rods or tubes in tension $k_{\mathrm{gtt}}$ is much higher so that it can be regarded as infinite.

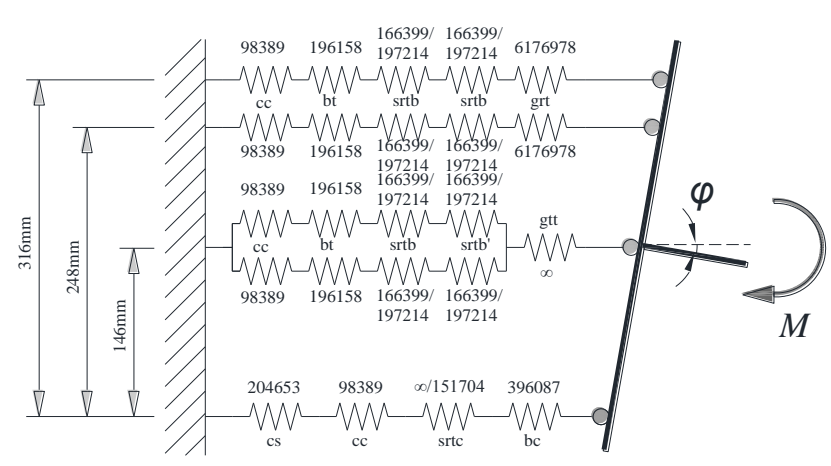

(a) Original model

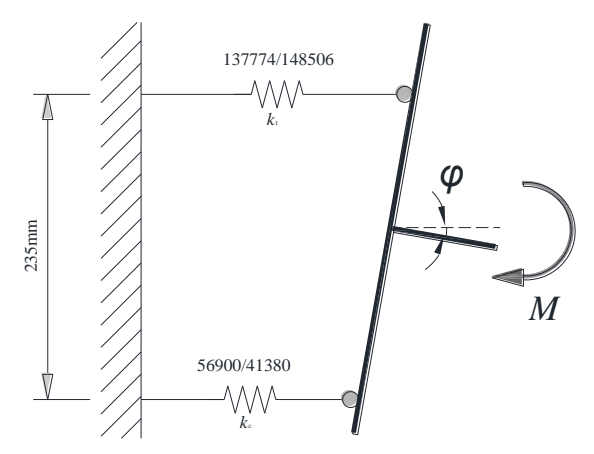

(b) Equivalent model

Fig. 16. The initial elastic stiffness of joint components (Unit: kN/m).

\section{Table 6}

The detailed illustration of the initial elastic stiffness of joint components.

Location of the joint The initial elastic stiffness (mm)


Therefore the joint initial rotational stiffness may be derived from Eq. (14), which was compared to the experimental mean values as indicated in Table 7. As can be seen from Table 7, it shows a high agreement between the theoretical and experimental results.

For a serially connected joint, the initial rotational stiffness will depend on the smaller value of the individual components. In this case, the initial rotational stiffness could be remarkably improved as the initial elastic stiffness of glulam column in transverse compression increases.

\section{Table 7}

Comparison between theoretical and experimental joint initial rotational stiffness.

\begin{tabular}{lllllll}
\hline $\begin{array}{l}\text { Series } \\
\text { reference }\end{array}$ & $\begin{array}{l}\text { No. of } \\
\text { replicates }\end{array}$ & $\begin{array}{l}t_{\mathrm{f}} \\
(\mathrm{mm})\end{array}$ & Stiffening & \multicolumn{3}{c}{ Joint initial rotational stiffness $S_{\mathrm{j} \text {,ini }}(\mathrm{kNm})$} \\
\cline { 5 - 7 } & 3 & 6 & Yes & $\begin{array}{l}\text { Experimental } \\
\text { results }\end{array}$ & $\begin{array}{l}\text { Analytical } \\
\text { results }\end{array}$ & $\begin{array}{l}\text { Difference } \\
(\%)\end{array}$ \\
\hline JT2 & 3 & 6 & No & 1767 & 2264 & +3.5 \\
JT3 & 3 & 8 & 1760 & 1722 & -2.1 \\
\hline
\end{tabular}

\subsection{Joint $M-\phi$ relationships and rotation capacity}

In order to easily obtain the joint $M-\phi$ relationships and rotational capacity directly from the force-displacement relationships of the individual spring components (see Fig. 8), the spring components model depicted in Fig. 7 can be replaced by a substitute one, as shown in Fig. 17. Thus the $M-\phi$ curves of the entire joint can be obtained, which is compared to the experimental results in Fig. 18. It should be pointed out that among the two series, the first joint specimen was under monotonic load, while the others were under cyclic load. Therefore the $M-\phi$ curves for specimens JT2-2, JT2-3, JT3-2 and JT3-3 is obtained by connecting the maximum load points of each cycle, with the symbol of "+" and "-." representing the two directions. It should be noted that, combining Eqs. (28) and (29) with Fig. 14(b), the rotation $\phi$ can be determined as:

$\phi=\frac{\delta_{t}+\delta_{c}}{h_{1}}$ 


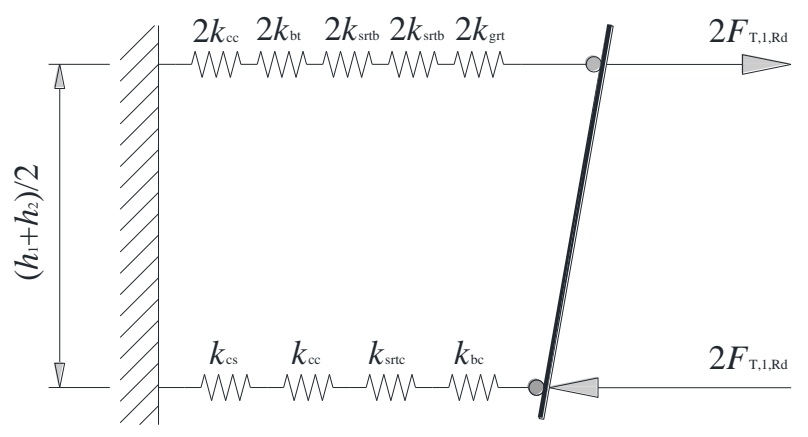

Fig. 17. Equivalent spring model for joint rotation behavior.

As can be seen from Fig. 18, the $M-\phi$ curves and rotation capacity between theoretical and experimental results of the entire joint agreed quite well, which proved the validity of the theoretical model. It should be pointed out that the two inflexion points in the theoretical curves refers to the T-stubs yielding and glulam yielding of columns or beams, respectively, so that it as a whole show non-linear behavior. Moreover, a comparison on the rotation capacity between theoretical and experimental values is provided in Table 8 , in which it shows the difference of $8.9 \%$ for series JT2 and $19.0 \%$ for series JT3. Most of the contribution of rotation capacity comes from the equivalent T-stub due to its mode 1 failure.

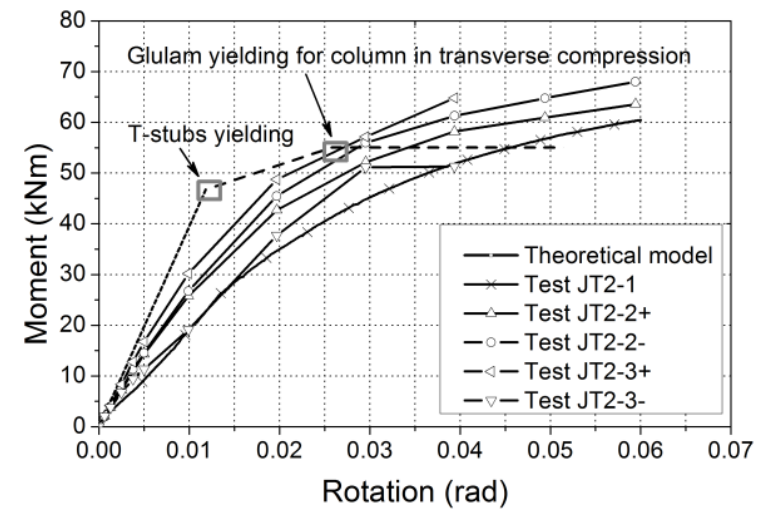

(a) Joint series JT2

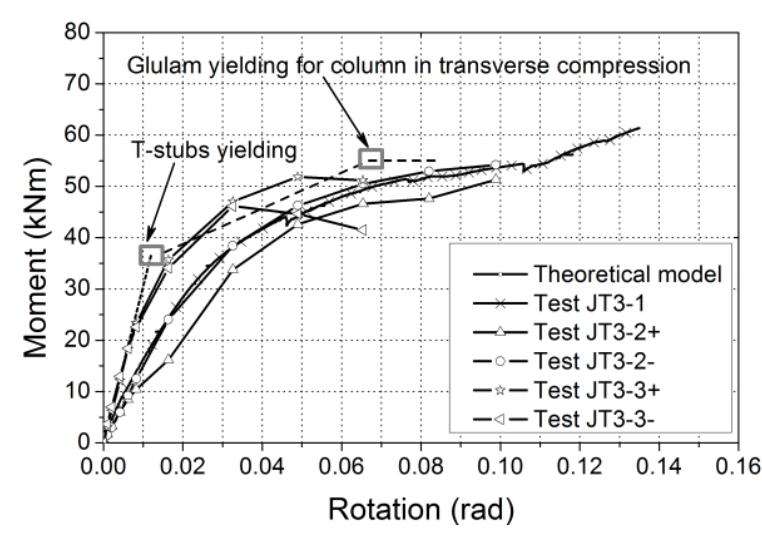

(b) Joint series JT3

Fig. 18. Moment-rotation curves for the joint specimens.

As an application, the theoretical model can well be used in finite element analysis (FEA) and parameter study of this kind of joint in the next investigation.

\section{Table 8}


Comparison between theoretical and experimental joint rotation capacity.

\begin{tabular}{lllllll}
\hline \multirow{2}{*}{$\begin{array}{l}\text { Series } \\
\text { reference }\end{array}$} & \multirow{2}{*}{$\begin{array}{l}\text { No. of } \\
\text { replicates }\end{array}$} & \multirow{2}{*}{$\begin{array}{l}t_{\mathrm{f}} \\
(\mathrm{mm})\end{array}$} & Stiffening & \multicolumn{3}{c}{ Joint rotation capacity $\phi_{\mathrm{Cd}}(\mathrm{rad})$} \\
\cline { 5 - 7 } & & $\begin{array}{l}\text { Experimental } \\
\text { results }\end{array}$ & $\begin{array}{l}\text { Analytical } \\
\text { results }\end{array}$ & $\begin{array}{l}\text { Difference } \\
(\%)\end{array}$ \\
\hline JT2 & 1 & 6 & Yes & 0.056 & 0.051 & -8.9 \\
JT3 & 1 & 8 & No & 0.105 & 0.085 & -19.0 \\
\hline
\end{tabular}

\section{Conclusions}

This paper presents a component method for calculating the moment resistance, initial stiffness and the rotation capacity of glulam beam-column connections with glued-in rods. Furthermore from the simplified spring component model, the failure modes and $M-\phi$ curves can also well be predicted.

The theoretical results of the presented method show a satisfactory agreement with that of experimental ones. And the predicted values are conservatively lower as compared to the experimental results. Also the substitute T-stub for steel box sections has been verified by the experimental results for both with and without a stiffener.

The potential applications of the theoretical method are FEA investigation, parameter analysis and optimization of the entire moment-resistant connections, which are the future research efforts. Furthermore, the analytical method can also be suitable to the joints for beam splices and column base, including steel-timber joints. As to the failure modes in application, mode 1 equivalent T-stub failure is preferred for its good ductile behavior while failure modes 2 and 3 should be prevented due to the difficulty and non-convenience of replacing/repairing and the poor plastic rotation behavior.

To prevent the premature local failure of glulam column in transverse compression or shear and also glulam beam in compression, some reinforcing measures should be provided, e.g., using self-tapping screws or glued-in rods.

Overall, the proposed method performed quite well in fulfilling the objectives of this investigation. Further validation testing involving the bearing strength of glulam column in 
shear and transverse compression is necessary, since the initial rotational stiffness is sensitive to them. FEA investigation, parameter analysis and optimization will be the focus of the next research.

\section{Acknowledgments}

This research work was supported by the National Science Foundation of China (Grant No. 51108233 and 51378256), which are highly appreciated.

\section{References}

[1] CEN - Comite Europeen de Normalisation. Eurocode 8: Design of structures for earthquake resistance, part 1-1: general rules, seismic actions and rules for buildings (EN 1998-1). Brussels; 2005.

[2] Leijten AJM. Requirements for moment connections in statically indeterminate timber structures. Eng Struct 2011; 33(11): 3027-32.

[3] Brühl F, Kuhlmann U, Jorissen A. Consideration of plasticity within the design of timber structures due to connection ductility. Eng Struct 2011; 33(11): 3007-17.

[4] Broughton JG, Hutchinson AR. Adhesive systems for structural connections in timber. Int J Adhes Adhes 2001; 21(3):177-86.

[5] Gustafsson PJ, Serrano E. Glued-in rods for timber structures - Development of a calculation model, Report TVSM-3056, Div of Struct Mech, Lund University, Sweden; 2001.

[6] Bainbridge RJ, Mettem CJ, Ansell MP. Bonded-in rod connections for timber structures-development of design methods and test observations. Int $\mathbf{J}$ Adhes Adhes 2002; 22(1):47-59.

[7] Yeboah D, Taylor S, McPolin D, Gilfillan R, Gilbert S. Behaviour of joints with bonded-in steel bars loaded parallel to the grain of timber elements. Constr Build Mater $2011 ; 25(5): 2312-7$. 
[8] Ling Z, Yang H, Liu W, Lu W, Zhou D, Wang L. Pull-out strength and bond behaviour of axially loaded rebar glued-in glulam. Constr Build Mater 2014; 65 (1): 440-9.

[9] Tlustochowicz G, Serrano E, Steiger R. State-of-the-art review on timber connections with glued-in steel rods. Mater Struct, 2011; 44(5): 997-1020.

[10]Buchanan AH, Fairweather, RH. Seismic design of glulam structures. Bull New Zeal Natl Soc Earthquake Eng 1993; 26(4): 415-36.

[11] Vašek M, Mikeš K. The Metal Joints for the Space Timber Structures-the Non-linear Behaviour. In: Proceedings of the world conference on timber engineering 1998. Montreux, Switzerland; 1998.

[12] Vašek M. Semi rigid timber frame and space structure connections by glued-in rods. In: Proceedings of the world conference of timber engineering. Miyazaki, Japan; 2008.

[13] Vašek M, Vyhnálek R. Timber semi rigid frame with glued-in-rods joints. In: Proceedings of the world conference on timber engineering 2006, Portland Oregon State University, Portland, United states; 2006.

[14]Fairweather RH. Beam column connections for multi-storey timber buildings. Master's thesis. Department of Civil Engineering, University of Canterbury; 1992.

[15]Buchanan AH, Moss PJ, Wong N. Ductile moment-resisting connections in glulam beams. In: Proceedings of NZSEE conference, Wairakei Resort, Taupo, New Zealand; 2001.

[16] Kangas J. Design of connections based on in V-form glued-in rods. In: Proceeding of the world conference of timber engineering, British Columbia, Canada; 2000

[17] Fragiacomo M, Batchelar M. Timber frame moment joints with glued-in steel rods. I: Design. J Struct Eng 2012; 138(6): 789-801.

[18] Fragiacomo M, Batchelar M. Timber frame moment joints with glued-in steel rods. II: Experimental investigation of long-term performance. J Struct Eng 2012; 138(6): 
$802-11$.

[19] Tomasi R, Zandonini R, Piazza M, Andreolli M. Ductile end connections for glulam beams. Struct Eng Int 2008; 18(3): 290-6.

[20] Andreolli M, Piazza M, Tomasi R, Zandonini R. Ductile moment-resistant steel—timber connections. Proc Inst Civ Eng Struct Build 2011; 164(2): 65-78.

[21] Jaspart JP. General report: session on connections. J Construct Steel Res 2000; 55(1): 69-89.

[22]CEN - Comite Europeen de Normalisation. Eurocode 3: Design of steel structures - Part 1.8: Design of joints (EN 1993-1-8:2005). Stage 49 Draft. Brussels; 2005.

[23]Lemonis ME, Gantes CJ. Mechanical modeling of the nonlinear response of beam-to-column joints. J Constr Steel Res 2009; 65: 879-90.

[24] Cachim PB, Franssen JM. Numerical modelling of timber connections under fire loading using a component model. Fire Saf 2009; 44(6): 840-53.

[25] Wald F, Mares Z, Sokol M, Drdácký F. Component method for historical timber joints. Banitopoulos CC, Wald F (Eds.). The paramount role of joints into the reliable response of structures: NATO science series, vol. 4 2000; 417-24.

[26]Zoetemeijer P. A design method for the tension side of statically loaded bolted beam-to-column connections. Heron 1974; 20(1): 1-59.

[27] Borges LAC. Probabilistic evaluation of the rotation capacity of steel joints. Master's thesis. University of Coimbra, Coimbra, Portugal; 2003.

[28] Girão Coelho AM. Characterization of the ductility of bolted end plate beam-to-column steel connections. PhD thesis. University of Coimbra, Coimbra, Portugal; 2004.

[29] Silva LS, Coelho AG. A ductility model for steel connections. J Construct Steel Res 2001; 57: 45-70.

[30]CEN - Comite Europeen de Normalisation. Eurocode 3: Design of steel structures - part 
1-1: General rules and rules for buildings (EN 1993-1-1:2005). Brussels; 2005.

[31] Van der Put TACM. Derivation of the bearing strength perpendicular to the grain of locally loaded timber blocks. Holz- als roh und werkstoff 2008; 66(6): 409-17.

[32] Jorissen A, Fragiacomo M. General notes on ductility in timber structures. Eng Struct 2011; 33(11): 2987-97.

[33] Volkersen O. Die Nierkreaftverteilung in zugbeanspruchten Nietverbindungen mit kostantes Laschenquerschmitten. Luftfahrtvorschung, Band 15, 1938; 41-7. [in German].

[34]Beg D, Zupančič E, Vayas I. On the rotation capacity of moment connections. J Construct Steel Res 2004; 60(3): 601-20.

[35]CEN - Comite Europeen de Normalisation. Eurocode 5: Design of timber structures Part 1-1: General rules and rules for buildings (EN 1995-1-1:2004). Brussels; 2004.

[36] British Standards Institution. BS EN 338:2009. Structural timber. Strength classes values: BSI; 2009.

[37]British Standards Institution. BS EN 1194:1999 Timber structures. Glued laminated timber. Strength classes and determination of characteristic values: BSI; 1999.

[38]British Standards Institution. BS EN 408:2010 Timber structures. Structural timber and glued laminated timber. Determination of some physical and mechanical properties: BSI; 2010.

[39] ISO. ISO-16670 Timber structures - joints made with mechanical fasteners - quasi-static reversed-cyclic test method. Geneva, Switzerland, 2003. 
Graphical Abstract (for review)

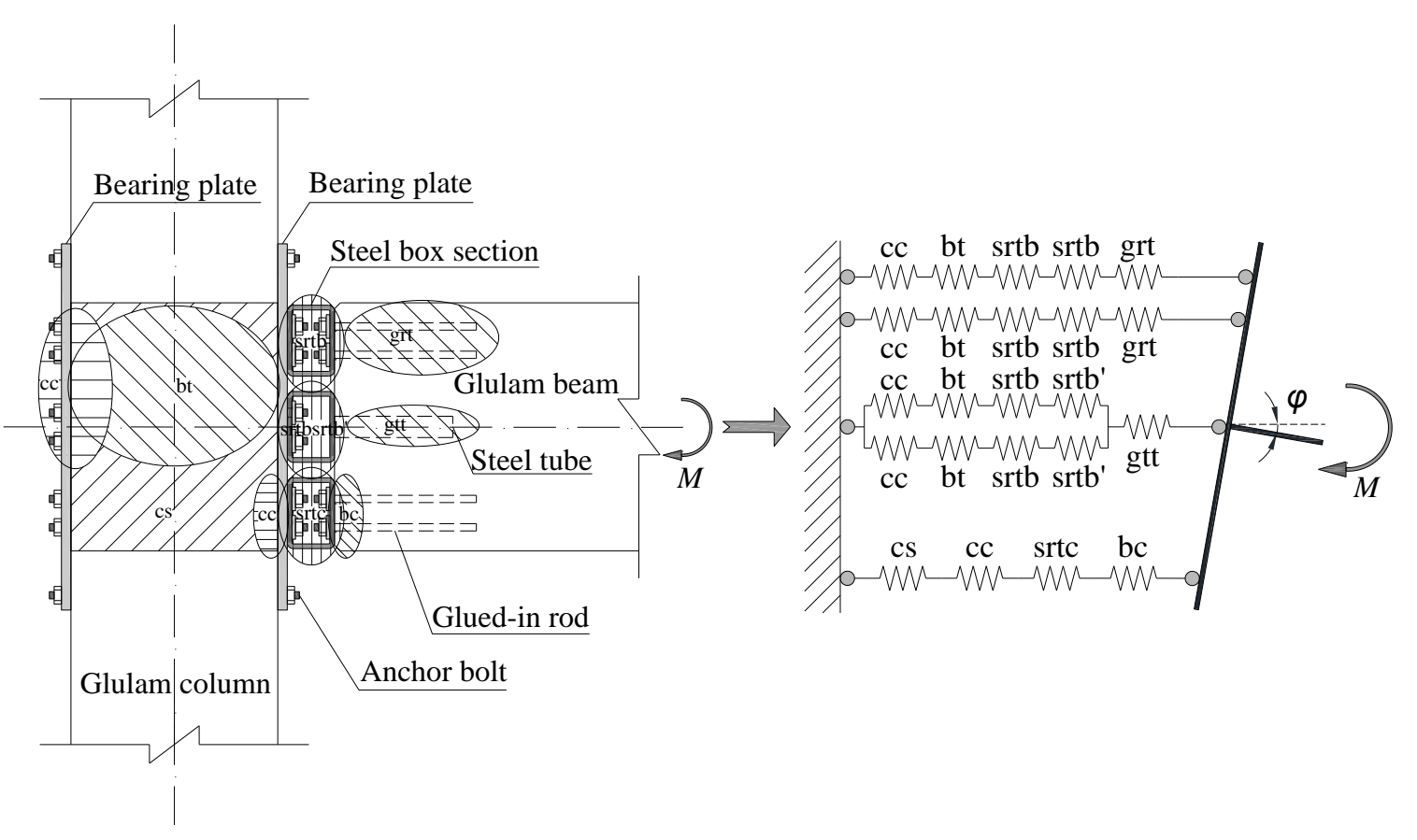

